\title{
DIE PASGA IN DIE NAGMAAL
}

\author{
J.L. Helberg \\ Departement Ou Testament \\ Potchefstroomse Universiteit vir Christelike Hoër Onderwys \\ POTCHEFSTROOM
}

\begin{abstract}
THE PASSOVER IN COMMUNION

Passover as well as Holy Communion implies reconciliation with God; reconciliation linked with a determining histarical event and communion with God and his believers. These are the essential and decisive elements. Holy Communion is more comprehensive than Passover and announces that Christ establishes the new coventant. $I$ implies foregiveness of sins and restoration of the relation with God in accordance with his commandments. This means life out of Christ; life in which his body is the believers' bread and wine, their daily nourishment. In Holy Communion Christ calls all believers to a battle against the enemy within themselves, and therefone, to eames self-examination and conversion. He requires that He himself, in faith should be appropriated as an expialory and life-giving gift Holy Communion stresses that communion with Christ and those who believe in Him is dominant in the lives of believers. II implies a life dominated by the expectation of the Advent of Christ.
\end{abstract}

\section{GOD SE GROOT VERLOSSINGSOPTREDE GEDENK IN 'N MAALTYD}

Daar bestaan ' $n$ verband tussen die Ou-Testamentiese Pasga en die Nuwe-Testamentiese Nagmaal. Wanneer Matteus (26:17) en Markus (14:12) die instelling van die Nagmaal beskryf, lè hulle 'n direkte verband met die Pasga (vgl. ook Schniewind, 1950:258); Ridderbos, 1972:356). Die datering van hierdie maaltyd en die kruisiging van Jesus lewer 'n probleem op (vgl. Johnson, 1951:572; Versteeg, 1980:32-41; Ridderbos, 1972:354-358). Hier hoef egter nie op die probleem ingegaan te word nie omdat dit nie die wese van hierdie artikel raak nie. Die verband tussen die Pasga en die Nagmaal blyk verder ook daaruit dat Jesus aansluit by die breek van brood en by die aangee van die beker met wyn (Matt 26:26,27; Mark 14:22,23; Luk 22:19,20). Die breek van die brood en die uitdeel van die beker wyn was 'n vaste bestanddeel van die viering van die Pasga.

Die Pasga is gevier ter herdenking van die uittog uit Egipte toe die eersgeborenes van die Egiptenaars met die dood getref is, maar die Israeliete aan die dood ontkom het. Hulle sou aan die dood ontkom as hulle 'n lam slag en van die bloed smeer aan die deurkosyn van die huis waar hulle die lam eet. Die lam moes saam met die ongesuurde brood geëet word. Die ongesuurde brood hou verband met die fees van die onge- 
suurde brood. Hierdie fees was oorspronklik 'n selfstandige landboufees maar het saam met die Pasga een fees geword (vgl. Eichrodt, 1961:122; Fensham, 1970:51,55; Kellerman, 1984:1078-1080; Noth, 1968:69; Otto, 1988:669-678; Rylaarsdam, 1962:664,668; Von Rad, 1968:79-80). Ook die beker met wyn was 'n bestanddeel van die Pasga, al word dit nie in die gedeeltes in Eksodus en Deuteronomium wat daaroor handel, genoem nie (Eks 12; Deut 16; Otto, 1988:680; insake die viering en die betekenis van die Pasga vgl. die artikel van H.F. van Rooy in hierdie uitgawe; ook De Vaux, 1968:484-493).

In die Pasga het dit gegaan om God se groot verlossingsdaad in Israel se geskiedenis toe God Israel op die drumpel van die dood gered het. Dit is 'n gebeurtenis wat hulle moes gedenk in 'n maaltyd. Daarin het hulle gemeenskap beoefen met God en met mekaar as lede van die verbondsvolk. Die maaltyd het gepaard gegaan met verkondiging van die groot verlossingsdade van God by die uittog van Egipte en het daartoe gedien om Israel vir nou en vir die toekoms op God te laat vertrou. In Matteus en Markus word die Nagmaal beskrywe in terme van God se groot verlossingsdaad in die geskiedenis; ook in die Nagmaal gaan dit om die gemeenskap deur middel van 'n maaltyd. Ook daar dien die maaltyd om dié wat glo, vir nou en vir die toekoms op God te laat vertrou.

\section{2. 'N MAALTYD OM GOD TE EER AS DIE ENIGSTE REGEERDER EN VERLOSSER}

In die Pasga staan God se mag en heerskappy sentraal (vgl. Fensham 1970:50). God het die uittog bewerk deur sy magsdade op staatkundige gebied sowel as in die natuur. Hy het die farao van Egipte gedwing om Israel te laat trek en het hom in die afgrond gestort deur hom 'n verpletterende neerlaag te laat ly by die Rietsee. In sy verlossingsoptrede het God veral gebruik gemaak van sy heerskappy oor die natuur. Dit kom duidelik uit in die plae waarmee Hy Egipte getref het en in die manier waarop Hy die Rietsee gebruik het om sy volk voor die aanstormende leër van Egipte te red. "Dit was die nag waarin die Here oor hulle gewaak het en hulle uit Egipte bevry het. Daarom behoort dié nag aan die Here en moet alle Israeliete en hulle nageslagte dié nag wakker bly" (Eksodus 12:42). Die Egiptiese gode was geassosieer met die natuur en natuurkragte. Deur sy magsdade in die natuur het God met die Egiptiese gode afgereken en gewys dat Hy die enigste God en Verlosser is; dat Hy die Here is (Eks 12:12).

God is die almagtige God. Hierdie aspek bied 'n perspektief op die gebeurtenisse rondom Golgota. Die Pasga sê dat God onder alle omstandighede in beheer van dinge is; ook wanneer die situasie verlore lyk, soos by die Rietsee. Dit is ook so wanneer 
Jesus doodgemaak word. Onder alle omstandighede kan die gelowiges bly vertrou, ook al lyk dit of Jesus 'n dodelike neerlaag ly. Dit gaan nie bloot om 'n koninkryk van Jesus nie, maar om "die koninktyk van my Vader" (Mat 26:29). Jesus tree nie slegs self op nie - daar gebeur ook dinge met Hom, want Hy is deur die Vader gestuur. Die Nagmaal verkondig dan ook nie bloot die liefde van Jesus nie, maar die liefde van God in Jesus. Die Nagmaal verkondig tegelykertyd God se mag en sy liefde, sy geregtigheid en sy liefde. Hy straf die mens se sonde, maar Hy straf dit aan sy eie Seun.

Die klem op God se almag hou in dat die gelowige nie kan volstaan met wat hy in die Nagmaal ontvang nie. Die verlossing wat God bewerk, is tegelykertyd 'n beslaglegging op die verloste. Deur die verlossing word hy onder die opdrag van God geplaas; word hy vrygemaak om God te dien (vgl. ook 6.4). Daarom getuig die Nagmaal nie net van verlossing nie, maar ook van God se straffende en tugtigende optrede. By geleentheid van die Nagmaal tree Jesus op teenoor Judas en Petrus. Jesus sê dat Judas Hom sal verraai. Hy kondig ook aan dat Petrus Hom sal verloën, en Hy volg dit na sy opstanding op met 'n gesprek met Petrus. Die Nagmaal hou dus ook verband met tug. Die Nagmaal is egter veral 'n maaltyd voor en saam met God.

\section{3. 'N MAALTYD VOOR EN SAAM MET GOD}

\subsection{Verbondsgemeenskap}

Die Pasga was nie bloot ' $n$ individuele saak nie, dit was 'n maaltyd saam met ander persone. In hierdie maaltyd is gemeenskap beoefen met mekaar en met God. Die maaltyd het getuig van 'n verbondenheid met mekaar. Hierdie verbondenheid hang saam met 'n verbondsverhouding. Dit blyk uit die verbondsterm die Here jou God, wat deel vorm van die aanduiding "Pasga vir die Here jou God " in Deuteronomium 16:1. Die verbondsverhouding veronderstel ' $n$ lewe in gehoorsaamheid aan God se gebooie (Eks 20:2; Deut 5:6; vgl. verder 6.4).

By die instelling van die Nagmaal praat Jesus van " die nuwe testament in my bloed" (Mat 26:28). Daarmee sluit Hy aan by die nuwe verbond waarvan Jeremia en Esegiël praat (Jer 31:31-34; Eseg 16:59-60; 37:26). Die nuwe verbond vervang die verbond van Sinaï maar vorm nie 'n wesenlike teenstelling daarmee nie. Dit hou wel in dat God ' $n$ ander benadering volg teenoor Israel wat sy wet nie onderhou het nie. Hulle het nie met God omgegaan soos hulle moes nie en het nie sy wil gevolg nie maar hulle eie kop. Dadelik na die uittog was dit al so, veral gedurende die reis deur die woestyn. Die wese van die tien gebooie, soos by Sinai gegee, was dat Israel ás 'n kind van God moes lewe, en daarom sóos 'n kind van God. In die nuwe verbond sal God Israel met vergewende genade benader en hulle van binne af bewerk. Hy self sal hulle leer: Hy 
sal sy wet in hulle binneste skrywe, op hulle hart skrywe. So sal Hy die verbondsverhouding daarstel en onderhou: Hy sal hulle God wees en hulle sal sy volk wees.

Die nuwe testament of verbond wat met Jesus intree, vorm dan ook nie 'n teenstelling met die verbond te Sinai nie; Jesus sluit vir die instelling van die Nagmaal aan by die Pasga. Daar vind wel 'n ingrypende verandering plaas, maar die verandering sentreer in Jesus self, in sy koms om die gebooie te onderhou en hulle in die harte van sy gelowiges te skrywe. Dit gaan in die Nagmaal, net soos in die Pasga, om 'n verbondslewe met God, 'n lewe wat gekenmerk word deur gehoorsaamheid aan sy gebooie.

\subsection{Geloofsgemeenskap}

Israel moes die Pasga hou as lede van een volk, die verbondsvolk. Hulle aanneming as volk van God het plaasgevind te Sinai (Eks 19:5), en die Pasga het die fondament gelê vir Israel se geboorte (Hos 2:2(5)); 'n geboorte tot die nuwe lewe van genade en gemeenskap met God. In die toekoms sou die Pasga dit ook telkens hernuwe (Keil, 1949(a):468; 1949(b):9). Die maatstaf om tot die volk van God te behoort en die Pasga te kan vier, was geloof in God - geloof in sy verlossende optrede. Dit moes uitkom in 'n geloofsdaad: bloed moes aan die deurkosyne gesmeer word (Eks 12:22). Wie nie sy geloof gestalte laat kry het in hierdie daad nie, is nie gered nie. Dit was nie bloed of geboorte wat bepaal het of 'n mens lid van hierdie verbondsvolk is nie (vgl. Rylaarsdam, 1952:921). Daarom was lidmaatskap nie beperk tot gebore Israeliete nie. Ook die vreemdeling wat hom laat besny het en sodoende met woord en daad sy geloof in God bely het, kon aan die Pasga deelneem (vgl. oor die vreemdeling Martin-Achard, 1971:409-412; Kellermann, 1973:979-991). Die vreemdeling was dan "soos 'n kind van die land" (Eks 12:48). Jesus se koms le nog groter nadruk op hierdie geloofsaspek en daarmee saam op die feit dat die verlossende genade nie tot Israel beperk is nie. Dit is inteendeel bedoel vir almal wat in Jesus Christus glo, in Hom as die Een wat deur God gestuur is om deur sy liggaam en bloed vir ons sonde versoening te doen. Hoewel die Nagmaal 'n sakrament is wat bedoel is as 'n maaltyd vir die plaaslike gemeente, is dit 'n verkondiging van die universele verlossing in Christus. Dit wil almal wat in Christus glo, sonder onderskeid in rang, stand, geslag of nasionaliteit saambind in gemeenskap met God en met mekaar, en in diensbaarheid aan God en mekaar.

\section{4. 'N MAALTYD OOR LEWE EN DOOD}

\subsection{Israel was materieel en geestelik in 'n doodsituasie}

Die Pasga getuig van God se genade, 'n genade wat nie slegs alle verdienste aan Israel se kant uitsluit nie, maar wat redding bewerkstellig uit 'n doodsituasie. Israel se posisic 
in Egipte word geteken as een waarin hulle aan die dood uitgelewer is. Hulle is nie alleen in 'n posisie van slawerny geplaas en geweldig verdruk nie, maar daar is ook 'n poging aangewend om hulle uit te roei. Hulle ondergangsituasie vind sy klimaks in die agtervolging deur die leër van die farao; hulle word teen die Rietsee vasgekeer. Die Here red hulle op wonderbaarlike wyse uit hierdie ondergangsituasie (Eks 14:9-31). Die Pasga getuig van hierdie redding uit 'n ondergang- of doodsituasie. Tegelykertyd tipeer dit God se optrede deur die hele geskiedenis van sy volk heen as 'n lewewekkende optrede (vgl. hieroor Helberg, 1983:85-87; 1988:6-7).

Ook geestelik is Israel uit 'n soort doodsituasie gered. Hulle geestelike lewe was op so 'n laagtepunt dat God as 't ware 'n nuwe begin met hulle maak deur sy selfbekendstelling as Jahwe (Eks 3:14; vgl. Helberg, 1988:69,73). Gedurende die uittog en die woestynreis betoon hulle hulleself as hardkoppig en totaal onwaardig om in ' $n$ verbondsverhouding met God te staan. Dit word baie duidelik bewys deur die gebeurtenis met die goue kalf (Eks 32). Israel is dus nie uit Egipte gered en tot die Pasga toegelaat omdat hulle voortreflik was nie. Hulle sou net so sterf soos die Egiptiese eersgeborenes indien hulle nie die bloed van die Paaslam aan hulle deurkosyne sou smeer nie (Eks 12:13,23). Hulle is slegs gered omdat daar deur middel van die lam plaasvervanging vir hulle was. Israel moes dan ook by geleentheid van die Pasga alle suurdeeg uit hulle midde verwyder. Suurdeeg was 'n teken van die oue, die verdwynende (vgl. Fensham, 1970:52). In die Pasga word daar met die oue weggedoen en word 'n nuwe begin gemaak. So moet die gelowiges van die nuwe bedeling die ou suurdeeg verwyder en 'n suiwer deeg wees deur' $n$ lewe van reinheid en waarheid te lei - ons Paaslam is immers geslag (1 Kor 5:7).

\subsection{Die Pasga spreek van versoening}

Die smeer van die bloed aan die deurkosyne het versoening versinnebeeld, want hisop is daarvoor gebruik (Eks 12:22). Besprenkeling met hisop is in die wet slegs voorgeskryf in verband met reiniging in die sin van versoening (Lev 15:49 e.v.; Num 19:18,19; Keil, 1949(b):14). Die offerbloed en die maaltyd daarna gee gestalte aan versoening met God en gemeenskap met Hom (Keil, 1949(b):20).

By die instelling van die Nagmaal praat Jesus van vergifnis van sondes deur sy bloed (Mat 26:28). Hy lè nie 'n direkte verband met die Paaslam nie; die verband wat hier gelê word, is met die bloed wat tydens die verbondsluiting by Sinaï teen die altaar en op die volk gesprinkel is (Eks 24:8). Hiermee plaas Jesus die Pasga binne die atmosfeer van 'n nuwe begin en van versoening van sondes (vgl. Ridderbos, 1972:360-361; 339-344 - teenoor Lietzmann wat twee teenoor mekaar staande Nagmaalstipes onderskei: 'n Jerusalemse tipe met 'n eskatologiese gedagte, en 'n Pauliniese met 'n soen- 
doodgedagte). Volgens Eksodus 24:8 is die een helfte van die bloed teen die altaar uitgegooi en dit versinnebeeld dat die volk se lewe oorgegee is aan God - 'n lewe wat deur die dood heen gegaan het en wat deurdring moet word deur sy genade. Hierdie lewe word dan weer deur die besprinkeling van die bloed op die volk aan hulle gegee as 'n lewe wat deur die genade van God herstel is (vgl. Keil, 1949(b):158). Die bloed wat op Israel gesprinkel is, was dus hulle merkteken as verbondsvolk. Wanneer Jesus na sy bloed verwys as die bloed van die nuwe verbond, dan wys hy na sy selfoorgawe aan die kruis as die enigste merkteken van sy nuwe volk, die volk wat in die nuwe verbond of testament mag deel (vgl. Versteeg, 1980:49).

\subsection{Versoening sowel as 'n nuwe lewe met Christus}

Soos hierbo gesê is, word die hele geskiedenis van Israel gekenmerk deur God se lewewekkende optrede wat telkens redding bewerk uit 'n situasie van ondergang en dood. In hierdie opsig trek die hele geskiedenis en die hele Ou Testament saam in Jesus Christus, naamlik in God se lewewekkende optrede deur Jesus se dood en sy opstanding. By die instelling val die klem op sy dood, en wel sy dood as versoening vir ons sondes. Tog is sy opstanding nie afwesig nie, maar vorm dit die agtergrond om sy dood sinvol te verstaan (vgl. Ridderbos, 1972:366). Sy dood is nie die laaste woord nie sy lewe is die laaste woord: daarom is die Nagmaal 'n maaltyd wat getuig van ons lewe deur sy dood en van ons uiteindelike vereniging met Hom: "Van nou af sal Ek nie weer van hierdie wyn drink nie tot op die dag wanneer Ek saam met julle die nuwe wyn in die koninkryk van my Vader sal drink" (Mat 26:29).

Hoewel die nadruk in die Nagmaal op die soendood van Christus en dus op versoening val, is dit nie al nie. Nagmaal impliseer ook 'n nuwe lewe in gemeenskap met Christus, 'n lewe volgens God se gebooie, saamgevat in die regte verhouding tot God en die naaste. Nagmaal kyk wel veral terug na die kruis, maar ook vorentoe na die hereniging met Christus, en ook na die lewe uit Christus in ons alledaagse bestaan en verhoudinge.

\section{5. 'N MAALTYD GEPAARD MET VERKONDIGING VAN 'N HISTORIESE GEBEURTENIS}

\subsection{Woordverkondiging oor 'n historiese gebeurtenis}

Israel is deur God onder ' $n$ verpligting geplaas om by die Pasga die geskiedenis daaraan verbonde aan hulle kinders te vertel (Eks 12:25-27). Daarmee is kennis van die reddende optrede van God aan die nageslag deurgegee sodat God geëer en geprys 
en gedien kan word. Woord, insluitende woordverkondiging, is een van die kenmerkendste elemente van die Ou-Testamentiese godsdiens. Reeds by die skepping het God telkens gesê dat iets moet gebeur. By die roeping van Abraham praat God met hom en speel die woord 'n grondliggende rol (vgl. Vriezen, 1962:238) - so ook by die roeping van Moses (Eks 3). Die profete se optrede word gekenmerk deur die formule: "So sè die Here". Die opdrag aan Israel by die instelling van die Pasga dat hulle hierdie verlossingsoptrede van God moet vertel, vorm deel van hierdie verkondigingskarakter van die Ou Testament.

Deur die opdrag dat Israel by die viering van die Pasga moet vertel van die reddende optrede van God, word tegelykertyd ' $n$ magiese benadering van die Pasga verhoed. Die Pasga het nie bloot bestaan uit die uitspreek van sekere formules wat dan die krag sou besit om iets tot stand te bring vir die deelnemers, of in hulle nie. Die Pasga was persoonlik en histories van aard. Dit het na ' $n$ bepaalde historiese gebeurtenis verwys, en het kennis van daardie gebeurtenis, asook 'n herdenking daarvan vereis. Dit was nie mities, misterieus of onkontroleerbaar van aard nie. Die Ou Testament het trouens baie nadruk gelê op die historiese of feitelike aard van sy godsdienstige gebruike en feeste. Selfs landboufeeste is met gebeurtenisse uit Israel se geskiedenis verbind. Op hierdie manier is Kanaänitiese beskouings , met hulle sterk mitiese inslag, by die wortel afgesny (vgl. Wright, 1953:432-433).

Ook die Nagmaal is direk verbind met 'n historiese gebeurtenis: die historiese gebeurtenis van Jesus Christus se dood. By die instelling daarvan verkondig Jesus ook waarom dit gaan. Wanneer Hy sê dat die Nagmaal tot sy gedagtenis gevier moet word (Luk 22:19), moet dit dus ook op hierdie historiese manier gedoen word. Dit moet gepaard gaan met die verkondiging van heilsfeite rondom hierdie historiese gebeurtenis. Nagmaal kan nie sonder woordverkondiging oor hierdie gebeurtenisse gevier word nie, hetsy deur 'n preek, hetsy deur verkondiging in 'n formulier. Nagmaal mag nie met 'n blote ritueel gevier word nie. Die instellingsformuliere mag nie 'n soort magiese formule word waardeur die elemente van brood en wyn 'n soort krag sou verkry wat verandering in die deelnemers sou bewerk nie. Die konsubstansiasieleer en die transsubstansiasieleer van Luther en van Rome onderskeidelik, moet dus afgewys word (vgl. Ridderbos, 1972:369,371). Die Bybelse begrip gedenk het met 'n eenmalige gebeurtenis van die verlede te doen en sluit 'n herhaling uit (vgl. Versteeg, 1980:60; Ridderbos 1972:370). Die konsubstansiasieleer en die transsubstansiasieleer moet verder afgewys word omdat hulle in stryd is met die hele Ou-Testamentiese benadering: eet van 'n offerande het vir die Israeliet nooit beteken om sy God te eet nie.

Die betekenis van die Nagmaal bestaan daarin dat God geloofsversterking en beseëling by die deelnemers bewerk deur sy Gees, nie deur brood en wyn nie. Hierdie versterking en beseëling gebeur wanneer hulle die gebeurtenis van die dood van Jesus in 
Die Pasga in die Nagmaal

die geloof gedenk, dit wil sê op hulle van toepassing maak (vgl. Versteeg, 1980:59).

Die benaderings van konsubstansiasie en van transubstansiasie devualeer nie alleen die woordverkondiging deurdat hulle daaraan 'n soort magiese krag toeken nie, maar verontpersoonlik ook die godsdiens. Die fokus val daar nie op God self nie maar op die elemente van die Nagmaal: die brood en die wyn. Formeel gesien, het die mens reeds in die paradys hierdie verkeerde weg opgegaan deur in die boom van kennis self 'n krag te sien wat kennis sou bewerk. Die mens het nie God self en sy woord (die verbod) in die fokus geplaas om so tot beoefening van ware kennis te kom nie, hy het dit nie langs die weg van geloof en vertroue en gehoorsaamheid gedoen nie.

Die Ou-Testamentiese godsdiens was nie natuur- of geografies-bepaald en gebonde soos dié van die buurnasies nie. Dit was inteendeel 'n historiese godsdiens - histories in die sin dat dit gegaan het om God se optrede in die geskiedenis. Dit was egter ook nie histories-gebonde nie maar het 'n bevrydende perspektief op verlede, hede en toekoms gebied.

\subsection{Integrering van verlede, hede en tockoms}

Israel moes in die Pasga 'n gebeurtenis uit die verlede herdenk (Eks12:14). Die Ou Testament lê sterk nadruk op die herdenking van God se werksaamheid in die verlede, in besonder op die uittog uit Egipte. Die uittog vorm as ' $t$ ware 'n refrein deur die $\mathrm{Ou}$ Testament. Hierdie feit benadruk God se werksaamheid in en sy heerskappy oor die geskiedenis. Die Ou-Testament verkondig nie 'n oombliksgodsdiens, 'n godsdiens wat net op die oomblik gerig is en net aktueel is nie. Anders gestel, die Ou Testament verkondig nie 'n eksistensialistiese godsdiens nie. Daarom vind die digter in Klaagliedere 3 in sy hopelose situasie dan ook sy krag daarin dat hy ter harte neem wat God nog gedurig in die verlede en tot dusver gedoen het: "Maar dít sal ek ter harte neem en om dié rede bly ek hoop: deur die liefde van die Here het ons nie vergaan nie; daar is geen einde aan sy ontferming nie, dit is elke môre nuut" (Klaagl 3:21-23). Israel moes in die Pasga dan ook die swaar wat hy in die verlede in Egipte gely het, herdenk. Daarmee saam moes hy ook die reddende optrede van God herdenk (Deut 16:3).

Ook Israel se reaksie op God se optrede moet nie bloot 'n oombliksbelewenis of oombliksoptrede wees nie. Daar word van hulle 'n ommekeer, bekering, verwag. Hierdie ommekeer bestaan volgens die Hebreeuse woord (sab) nie slegs uit 'n innerlike verandering nie, maar is die uiterlike gevolg van 'n totale ommekeer van 'n mens se hele lewe (vgl. Wright, 1953:507-508). Ook in die Nagmaal moet die deelnemers die reddende optrede van God herdenk, sy reddende optrede in Christus. En hierdie herdenk sluit nie net 'n verstandelike aksie in nie, maar 'n betrokkenheid met die hele 
lewe (vgl. Versteeg, 1980:59).

God se optrede in die verlede en die herdenking daarvan deur sy volk bly nie in die verlede vassteek nie. Sy optrede word voortgesit in die hede, en sy volk van vandag is vir vandag daarby betrokke. Die Pasga herdenk "die nag waarin die Here oor hulle gewaak het en hulle uit Egipte bevry het. Daarom behoort dié nag aan die Here en moet alle Israeliete en hulle nageslagte dié nag wakker bly"(Eks 12:42). "'Dis nie net julle met wie Ek hierdie verbond onder eed sluit nie.' Hy sluit die verbond met almal wat vandag hier saam met ons voor Hom, die Here ons God staan, maar ook met hulle wat nie vandag hier saam met ons is nie"(Deut 29:14). Deuteronomium 5:3-4 lê die klem nog sterker op die effek wat God se optrede in die verlede vir vandag het: "Dit is nie ons voorvaders met wie $\mathrm{Hy}$ die verbond gesluit het nie, maar met ons, ons almal wat hier is en nou lewe. Ja, met julle persoonlik het die Here op die berg uit die vuur uit gepraat".

Ook in die Nagmaal gaan dit nie bloot om wat Christus in die verlede gedoen het nie. Daarom is die Nagmaal nie bloot ' $n$ gedagtenismaaltyd nie. Dit is nie ' $n$ gebeurtenis waarin daar slegs van ons kant 'n werksaamheid uitgaan, naamlik om te gedenk, en niks meer as dit nie (Zwingli; vgl. die artikel oor die Reformasie). Soos by die nag waarin Jesus die Nagmaal ingestel het, is Hy ook vandag tydens die Nagmaal by ons teenwoordig en werksaam deur sy Heilige Gees.

Die Nagmaal het ook betrekking op die toekoms. Hierdie fees wat so belangrik is dat dit een van die enigste twee sakramente is, word deur Jesus verbind met die Pasga. Die Pasga herdenk'n gebeurtenis toe Israel nog op pad was na die beloofde land; nog aan die begin van daardie pad. Israel is wel klaar uit Egipte bevry maar het nog nie in die land aangekom nie. Die fees gaan dus nie oor 'n situasie van gearriveerdheid nie. Die deelnemers se oog word nie net op die verlede en die hede gevestig nie, maar ook op God se verlossende optrede in die toekoms. Die beloofde land word in die Ou Testament beklemtoon, maar die klem val daarby sterk op die aspek van die belofte, van die toekoms, van iets wat nog sy ware vervulling moet kry. Roubos (1981:515) wys dan ook daarop dat die toekomsverwagtings hoe langer hoe meer verbind is aan die viering van die Pasga (vgl. ook Otto, 1988:680).

Ook Christus wys ons op die toekoms wanneer Hy die Nagmaal instel: "Van nou af sal Ek nie weer van hierdie wyn drink nie tot op die dag dat Ek saam met julle die nuwe wyn in die koninkryk van my Vader sal drink" (Mat 26:29). Die Nagmaal maan ons om nie net vir nou te leef nie maar om ook en veral uit eskatologiese verwagting te leef. Ons moet leef uit die verwagting om saam met Christus in die koninkryk van die Vader te wees. Aangesien Hy op die oomblik in die hemel aan die regterkant van sy Vader is, is ons burgerskap ook in die hemel (Efes 2:6,12). Nagmaal verkondig aan die een kant 
dat ons lewe waarde het omdat Christus vir ons gesterf het en aan die ander kant verkondig Nagmaal dat alles relatiewe waarde het; alles moet vanuit ons verhouding met Hom en sy gelowiges bepaal word.

\section{VERSKIL TUSSEN PASGA EN NAGMAAL}

\subsection{Die Nagmaal bring verskillende lyne saam}

Die Nagmaal is nie net bloot ' $n$ herhaling van die Pasga nie (vgl. Versteeg, 1980:34). Jesus bring verskillende gedagtelyne uit die Ou Testament saam in Homself, naamlik die lyn oor die Pasga, oor die dienaar van die Here en oor die nuwe verbond.

In die Pasga was die aandag gevestig op die reddende optrede van God wat in sy oordelende optrede by dié wat Hom dien, verbygaan. In die profesie oor die lydende dienaar van die Here was die aandag egter gevestig op die lyding en oordeel wat sy dienaar moes ondergaan om daardeur verlossing teweeg te bring. Dit is ook die geval in die Nagmaal: vergewing vir dié wat aan God behoort, maar deur middel van die lyding en oordeel oor sy Seun. Hierdie verbandlegging tussen Jesus en die lydende dienaar blyk ook uit ander Skrifgedeeltes in die Nuwe Testament (Hand 8:32-33 en Jes 53:7; Rom 4:25 en Jes 53:5,12; Rom 8:32 en Jes 53:6; Gal 1:4 en Jes 53:10; 1Petr 2:24 en Jes 53:5,12; vgl. Versteeg, 1980:47). Die woorde: "Dit is my bloed, die bloed van die nuwe testament" (Mat 26:28) is 'n verwysing na die nuwe verbond waarvan die profete Jeremia en Esegiël praat (Jer 31:31-34; Eseg 16:59-60; 37:26). Jesus sê dat deur sy dood die nuwe verbond aanbreek, en hierdie nuwe verbond behels vergifnis van sonde, herstel van die verhouding met God en 'n lewe van gewillige gehoorsaamheid aan God (vgl. Versteeg, 1980:48).

\subsection{Die Nagmaal benadruk dat die vyand binne ons is}

In die Pasga was die aandag gerig op die eksterne vyand, naamlik Egipte. By die instelling van die Nagmaal word die aandag nie op 'n eksterne vyand gevestig nie, nie op Egipte of op Rome of op enige ander vyand nie. Jesus Christus as die Messias vestig die aandag nie op die nasionale verwagtings en die nasionale vyand, soos vergestalt in plekke en lande, wat deur oorlog of ander geweld beveg moet word nie. Sy koninkryk is nie van hierdie werreld nie maar is anders van aard. Hy oorwin deur versoening tussen God en mens te bewerkstellig deurdat Hy sy lewe afle. Hy wys dat die gevaar en die vyand op ' $n$ ander plek is, in ons eie midde en in eie boesem. Hy stel die verraad van sy eie apostel Judas aan die kaak; ook die feit dat een van die ander apostels, Petrus, Hom sal verloën. By die Nagmaal kom daar dus 'n verenging sowel as 
'n verbreding van perspektief. Die aandag is nie op die nasionale entiteit gerig nie maar op die individuele verhouding tussen die gelowige en Christus; op die persoonlike daad van gedenk en glo. Daarmee is daar tegelykertyd 'n verbreding, ' $n$ universalisering van perspektief. Elkeen wat sy verlossing sien in die versoening met God deur die liggaam en bloed van Jesus Christus, word deur die Nagmaal betrek. Die fokus verskuif weg van die beërwing van die land na die beërwing van die nuwe aarde (Mat 5:5).

Die erfgename is egter alleen dié wat aan die vereistes van die koninkryk van die hemel voldoen (Mat 5:3-12). Jesus Christus se optrede teenoor Judas en Petrus plaas die Nagmaal binne die atmosfeer van die oproep tot ernstige selfondersoek en bekering. Dit gaan oor die greep wat die ware vyand, die subtiele vyand, in ons eie hart en lewe uitoefen.

\subsection{Die Nagmaal is nie plekbepaald of tydsbepaald nie}

Die Pasga was verbind aan 'n bepaalde plek (Deut 16:2,5,6). Hier hoef nie ingegaan te word op die probleem in hoever die plek op Jerusalem betrekking het nie (vgl. daarvoor die kommentare). Die Pasga is verder veral met die beloofde land geassosieer: "Wanneer julle in die land kom wat die Here aan julle gaan gee soos Hy beloof het, moet julle hierdie verpligting nakom" (Eks 12:25). In teenstelling tot Israel se bure met hulle natuurgodsdiens het die klem reeds in die Ou Testament nie op die ruimtelike aspek geval nie, maar op die aspek van God se optrede in die geskiedenis. Vandaar dat Israel se feeste met historiese gebeurtenisse verbind is (vgl. 5.1). Die Pasga herdenk dan ook God se optrede by die uittog uit Egipte, dit herdenk nie die intog in Kanaän nie. Die land is nie die grond vir die Pasga nie, maar alleen die plek waar dit onderhou word. Ons sou die land die vrug van die uittog en die Pasga kon noem.

In die Nagmaal is die element van die plek selfs heeltemal afwesig. Dit geld van Jerusalem, die land of enige ander plek. Die fees sentreer om die historiese gebeurtenis wat met Jesus Christus plaasgevind het (soos ook die geval is met die ander groot feeste, vgl. die Pinkstergebeurtenis).

Sover dit die viering van die Nagmaal betref, het Jesus die feeste nie net gehistoriseer sodat die ruimtelike element verdwyn het nie, maar Hy het ook die feeste gepersonifieer, sodat die tydselement verdwyn het. Die Nagmaalsviering word nie aan 'n bepaalde tyd van die jaar verbind nie, maar aan Jesus Christus as persoon - Hy wat deur die eenmalige feitelike gebeurtenis van sy dood en opstanding die ruimtelike element sowel as die tydselement van die viering gerelativeer het. Die beheersende faktor is gemeenskap met Jesus Christus wat vir ons sonde gesterf het en die dood oorwin het, 
asook gemeenskap met sy gelowiges. Nagmaal roep ons dus op om te besin wat die kern en wese van die godsdiens is wat in ons lewe en verhoudinge deurslaggewend is en wat die voorkeurorde daarin is.

\subsection{Die Nagmaal lê die klem op die geloof}

Die klem val in die Nagmaal op die verbandlegging met Christus deur die geloof van die deelnemers en nie op die aanskoulike of op die seremoniele nie. Israel moes die eerste Pasga haastig eet omdat hulle haastig uit Egipte vertrek het (Eks 12:11). Later is dit blykbaar verander want volgens latere tradisie het hierdie bepaling slegs op die eerste Pasga betrekking gehad (vgl. Rylaarsdam, 1952:921). Dit was nie 'n deel van die wesentlike betekenis van die Pasga nie. Die wesentlike betekenis het te doen gehad met die verlossing van God deur sy wonderbare optrede. Die wyse van viering deur haastige optrede het tot die bykomstige behoort. Jesus Christus het by die instelling van die Nagmaal dan ook nie by hierdie wyse van viering aangesluit nie, maar dit inteendeel op 'n rustige manier met sy dissipels aan tafel gevier (Luk 22:14: vgl. MacArthur, 1987:27).

Verder het Jesus Christus nie aangesluit by die eet van die paaslam nie maar by die brood en beker met wyn; Hy vervang die paaslam met Homself (vgl. Schilder, 1930:236). Hoewel Hy elders met die paaslam in verband gebring word (1 Kor 5:7), doen Hy dit tog nie self by die instelling van die Nagmaal nie. Sy bloed, waarvan Hy praat, verwys nie na die bloed van die paaslam nie, maar na die bloed wat by die seremonie van verbondsluiting om die helfte teen die altaar en op die volk gesprinkel is (Eks 24:8). Hy gebruik nie vleis en bloed om sy liggaam en bloed af te beeld nie, maar brood en wyn. Daarmee tree hy weg van die aanskoulike, in die sin van die werklike substansie, en sluit Hy sterker aan by 'n simboliese voorstelling. Die brood en die wyn is trouens blote simbole en besit in hulleself geen krag of betekenis nie. As simbole dien die brood en wyn daartoe om die deelnemer te wys na Jesus Christus self, nie na sy gefragmenteerde liggaamsdele of substansie nie. Die simbole wys na Hom wat, deur middel van sy liggaam en bloed, Homself vir ons gegee en vir ons sondes betaal het, $\mathrm{Hy}$ uit Wie ons moet leef. Jesus se woorde "dit is my liggaam" en "dit is my bloed" moet in hierdie sin verstaan word. Dit is nie nodig om 'n teenstelling te sien tussen hierdie weergawe (Ridderbos, 1972:358-360) en die betekenis "dit is Ekself" (Versteeg 1980:42-43; Schniewind, 1950:260) nie. Nagmaal wil die geloof in Christus bevestig en versterk en wil oproep tot ' $n$ lewe uit Hom, 'n lewe volgens die gebooie. Die Nagmaal is dus deur en deur persoonlik. Daarom bevestig en versterk die Nagmaal nie net die geloof in Christus nie maar eis dit ook. Die Nagmaal vra persoonlike geloof van die deelnemer (Versteeg, 1980:53), geloof in Christus as Persoon, geloofsgemeenskap met Hom wat saam met die Vader Gasheer is, maar tegelykertyd en veral die gawe is, Hy 
wat Homself as maaltyd gee, as brood van die lewe (Joh 6:32,33,37-40,57). Dit gaan om geloof wat bevestig word in ' $n$ lewe wat aan God gegee is.

Die gedenk en glo by die Nagmaal is dus nie 'n blote verstandelike handeling waarin aangeneem word dat Jesus gesterf het nie, of waarin slegs aangeneem word dat $\mathrm{Hy}$ vir ons versoening bewerk het nie. God se daad van versoening is nie neutraal nie maar is 'n soewereiniteitsdaad. Dit laat 'n mens nie vryblywend nie maar vra dat die gawe deur die geloof toegeëien word; dit la beslag op jou, dit eis jou lewe op vir Hom wat sy lewe vir jou gegee het. Die Nagmaal wys nie net na Jesus Christus se vervulling van die pasga as offer nie maar na sy vervulling van die hele Ou-Testamentiese offerdiens. Ja, meer nog, dit wys na die vervulling van die ou verbond en die totstandbrenging van die nuwe verbond. Hierdie nuwe verbond skenk vergewing van sonde, maak 'n lewe met God volgens sy gebooie moontlik, bring dit tot stand en eis dit ook ("Drink almal daaruit, want dit is my bloed, die bloed waardeur die verbond verseël word en wat vir baie vergiet word tot vergewing van sondes", Mat 26:27-28; vgl. Ridderbos, 1972:360361). Die brood en wyn - daaglikse voedsel van Israel - sê dus ook dat Jesus die daaglikse voedsel van die gelowiges is. Hy is die ware brood van die lewe (Joh 6:35).

Wat die gebeurtenis van die Nagmaalsviering betref: dit is 'n maaltyd, 'n geleentheid van gemeenskapsbeoefening, een waarin Jesus Christus in die geloof toegeëien word as die gawe van versoening en lewegewing. In hierdie gemeenskapsbeoefening is Jesus Christus saam met die Vader die Gasheer. Hy vra geloofsgemeenskap met Hom, maar dan ook met die ander deelnemers.

Jesus Christus het die Paasfees gevier om sodoende die wet na te kom, net soos $\mathrm{Hy}$ Hom laat besny het. Hy het die Pasga in Homself tot vervulling gebring en daarmee 'n einde daaraan gemaak. Hy het die Pasga getransendeer deurdat Hy deur sy dood en opstanding die nuwe verbond tot stand gebring het. Hy bewerk vergewing en Hy roep ons wat die Nagmaal vier, op om geloofsgemeenskap met Hom te beoefen, van Hom te getuig, uit Hom te leef en ons lewe so in te rig dat ons oog gevestig is op sy koms. Dit impliseer dat ons die betreklike waarde van alle dinge in ons lewe sal besef.

\section{KONKLUSIE}

Die Pasga en die Nagmaal stem daarin met mekaar ooreen dat dit om 'n maaltyd gaan waarin versoening met God versinnebeeld word, waarin sy verlossende optrede wat in 'n ingrypende historiese gebeurtenis plaasgevind het, gedenk word en waarin gemeenskap met Hom en sy gelowiges beoefen word. Dit is die wesenlike en beslissende elemente; die wyse van viering, die kultiese elemente en die seremoniële elemente, is sekondêr. 
Die Nagmaal verskil met die Pasga daarin dat ook ander openbaringslyne wat in Jesus Christus saamtrek, in die Nagmaal vervat is. Hy vervul die Pasga deurdat Hy die eintlike uittog bewerkstellig. Hierdie uittog is die bevryding uit die slawerny wat dit onmoontlik maak om God te dien. Jesus Christus bewerkstellig die bevryding as die lydende dienaar; deur sy soendood bring $\mathrm{Hy}$ die nuwe verbond tot stand. Dit behels vergifnis van sonde, herstel van die verhouding met God. Dit is 'n lewe uit Christus, 'n lewe waarin sy liggaam en bloed die gelowiges se brood en wyn is, hulle daaglikse voedsel. In die Nagmaal is Hy veral die gawe - brood en wyn - hoewel ook die Gasheer saam met die Vader. Jesus Christus benadruk dat die groot vyand van wie ons verlos moet word, nie buite ons is, soos Egipte of Rome nie, maar binne ons. Hy roep alle deelnemers aan die Nagmaal op tot ernstige selfondersoek en bekering, en tot geloofstoeëiening van Hom as versoenende en lewende gawe. Sy erfgename is alleen die wat aan die vereistes van die koninkryk van die hemele voldoen. Hulle beërf nie die land nie maar die nuwe aarde. Nagmaal benadruk dat die gemeenskap met Christus en die wat in Hom glo, allesbeheersend is in die lewe van die gelowiges. Hierdie gemeenskap moet ook uitkom in 'n nuwe lewe, 'n lewe volgens God se gebooie, 'n lewe beheers deur die verwagting van die koms van Jesus Christus.

\section{BIBLJOGRAFIE}

DE VAUX, R. 1968. Ancient Israel: Its life and institutions. London : Darton, Longmann \& Todd. EICHRODT, W, 1961. Theology of the Old Testament. I. London : SCM

FENSHAM, F.C. 1970. Exodus. Nykerk: Callenhach. (POT.)

HELeERG, J.L. 1983. Verklaring en prediking van die Ou Teslameni. Potchefstroom : Potchelstroomse: Tcologiese Publikasics.

HFLAFRG, J.L. 1988. Die Here regeer: openbaringslyn deur die Ou Testament. Pretoria : N.G. Kerkboekhandel.

JOHNSON, S.E 1951. The Gospel according to S1. Mallhew. Nashville : Abingdon. (The Interpreter's Bible, VII)

KEIL, C.F. 1949(a). The firs bonk of Moses. Grand Rapids : Eerdmans

KEIL, C.F. 1949(h). The second bonk of Moses. Grand Rapids: Eerdmans.

KEI.LER MANN, D. 1973. gar. (In ThWal, I. SIuligarl : Kohlhammer, p. 979-991.)

KELLERMANN, D. 1984. massdi. (In ThWal, IV. Stultgart : Kohlhammer, p. 1074-1081.)

MACARTHUR, J. 1987. The Lord's Supper. Chicago: Moody Press

MARTIN-ACHARD, R. 1971. gar, als Fremdling weilen. (In ThWAT, I. p. 409-412.)

NOTH, M. 1968. Das zwcile Buch Mose: Exodus. Gottingen : Vandenhoeck \& Ruprecht (ATD,V)

RIDDERBOS, H N. 1972. De komst van hel koninkrijk. Kampen : Kok.

OTTO. E. 1988. pasah. (In ThWAT, VI. Siuligar1 : Kohlhammer, p. 659-682)

ROUBOS, $K$. 1981. Bijbelse insiellingen: Bijzondere dagen en jaren (In Van der Woude, A.S. red. Bijbels Handhoek, I. Kampen : Kok, p. 508-520.]

RYLAARSDAM, J.C. 1952. The book of Exodus. New Yark : Abingdon. (The Interpreter's Bible, I.)

RYLAARSDAM, J.C. 1962. Passover and feast of unleavened bread. (In The Interpreter's Dictionary of the Bible, 11I. New York: Ahingdon, p. 663-668.)

SCHILDER, K. 1930. Christus in zijn lijden. I. Kampen : Kok.

SCHNIEWIND, J 1950. Das Evangelium nach Mallhaus. Gölingen : Vandenhoeck \& Ruprecht. 
VERSTEEG, J. 1980. Hel avondmaal volgens hel Nieuwe Teslament. (In Van 't Spijker, W. Balke, W. c. a., reds. $B$ ij brond en beker: leer en gebruik van het heilig avondmaal in het Nieuwe Testament en de geschiedenis van die westerse kerk. Goudriaan : De Groot, p. 9-64).

VON RAD, G. 1968. Das funfte Buch Mose: Deuternnomium Gottingen : Vandenhoeck \& Ruprecht. (ATD, VIII)

VRIEZEN, TH.C. 1966. Honfdlijnen der theologie van hel Oude Testament. Wageningen : Veenman.

WRIGHT, G.E. 1953. The book Deuteronomy. New York : Ahingdon. (The Interpreter's Bible. II.) 
